\author{
Marek Rawski \\ Katedra Marketingu \\ Uniwersytet Ekonomiczny w Krakowie
}

\title{
Zróżnicowanie źródeł informacji marketingowej w przekroju rodzaju działalności - wyniki badań
}

\section{Streszczenie}

Celem artykułu jest ukazanie, jakie jest zróżnicowanie znaczenia źródeł pozyskiwania informacji marketingowej przez przedsiębiorstwa prowadzące odmienne rodzaje działalności (działalność wytwórcza, usługowa, handlowa) na polskim rynku. Bazę informacyjną formułowanych tez stanowią wyniki badań przeprowadzonych przez Katedrę Marketingu Uniwersytetu Ekonomicznego w Krakowie w 2013 r. nt. zakresu i uwarunkowań wykorzystania marketingu przez przedsiębiorstwa. Dla przedsiębiorstw wszystkich rodzajów działalności ważność poszczególnych źródeł informacji jest taka sama. Zdecydowanie dominuje własne doświadczenie i intuicja, a najmniejsze znaczenie mają badania zlecane wyspecjalizowanym agencjom. Zróżnicowanie znaczenia wykorzystywania źródeł informacji przez przedsiębiorstwa w przekroju rodzaju działalności jest niewielkie. Przedsiębiorstwa wytwórcze częściej wykorzystują gotowe informacje pochodzące z różnych źródeł zewnętrznych. Przedsiębiorstwa usługowe częściej wykorzystują własne badania marketingowe, częściej zlecają badania wyspecjalizowanym agencjom rynku i częściej korzystają z własnego doświadczenia i intuicji. Przedsiębiorstwa handlowe częściej wykorzystują własne dane ewidencyjne.

Słowa kluczowe: marketing, informacja marketingowa, pierwotne źródła informacji, wtórne źródła informacji, zewnętrzne źródła informacji, wewnętrzne źródła informacji. 


\section{Wprowadzenie}

W warunkach współczesnej gospodarki rynkowej sukces przedsiębiorstwa zależy w dużej mierze od umiejętności wykorzystania w procesie zarządzania firmą marketingu. Podstawową determinantą skuteczności i efektywności decyzji marketingowych jest umiejętność określenia, uzyskania dostępu, oceny oraz wykorzystania potencjalnych źródeł informacji. Jest wiele źródeł informacji marketingowych, a rola każdego z tych potencjalnych źródeł jest odmienna dla przedsiębiorstw i zmienna w czasie.

Głównym celem publikacji jest próba ukazania znaczenia różnych źródeł pozyskiwania informacji marketingowej przez przedsiębiorstwa prowadzące różny rodzaj działalności (wytwórcza, usługowa, handlowa) na polskim rynku oraz wskazanie tych cech przedsiębiorstw i cech obsługiwanych przez nie rynków, które wywołują istotne różnice znaczenia poszczególnych źródeł informacji marketingowej.

\section{Metodyka badań}

Źródła informacji marketingowej wykorzystywane w procesie gromadzenia informacji można grupować w różnych przekrojach. Podział na źródła pierwotne i źródła wtórne ma istotne znaczenie między innymi ze względu na koszty pozyskiwania informacji [Kaczmarczyk 2002, s. 136-139]. Źródła pierwotne pozwalają na zebranie informacji specjalnie w celu zaspokojenia istniejących potrzeb informacyjnych decydenta - marketera (np. cechy rzeczy, osób, zdarzeń, stanów) [Rawski 2012, s. 258]. Źródła wtórne to takie, które pozwalają pozyskać informacje już istniejące, zebrane dla realizacji innych celów, niezwiązanych z istniejącymi potrzebami decydenta - marketera [Sojkin 2009, s. 74-89]. Przyjmując za kryterium podziału granice organizacyjne przedsiębiorstwa, źródła wtórne i pierwotne można podzielić na wewnętrzne (tkwiące w przedsiębiorstwie) i zewnętrzne (znajdujące się w otoczeniu przedsiębiorstwa). Jest to klasyczne ujęcie, ale nie jedyne. W przeprowadzonych badaniach wykorzystano inną klasyfikację. Wykorzystując własne doświadczenie wynikające z badań prowadzonych w 1999 r. przez Katedrę Marketingu Akademii Ekonomicznej w Krakowie (zob. [Pilarski i Rawski 1999, s. 61-86]) oraz opierając się na badaniach innych ośrodków akademickich (zob. np. [Dietl 1998, s. 13-17; Wilmańska-Sosnowska 2001, s. 573; Kędzior 1997, s. 20-23; Mazurek-Łopacińska 2002, s. 12-13; Fonfara 2001, s. 19-26; Kowal 2012, s. 210-216; Szostek 2012, s. 2-9]), uwzględniono następujące źródła informacji: własna ewidencja, własne obserwacje i doświad- 
czenia, własne badania marketingowe, wyspecjalizowane agencje badań rynku, źródła wtórne zewnętrzne.

Bazę informacyjną formułowanych tez stanowią wyniki badań przeprowadzonych przez Katedrę Marketingu Uniwersytetu Ekonomicznego w Krakowie w 2013 r. nt. zakresu i uwarunkowań wykorzystania marketingu przez przedsiębiorstwa. W realizowanym projekcie badawczym autor był odpowiedzialny za rozeznanie problematyki roli informacji marketingowej $\mathrm{w}$ procesie podejmowania decyzji rynkowych przez przedsiębiorstwa. Badanie miało przebieg dwufazowy i wieloetapowy. Posłużono się hybrydową metodą rekrutacji respondentów (przedsiębiorstw i ich przedstawicieli), łączącą rekrutację telefoniczną i internetowe zaproszenia do udziału w badaniu. Dane pierwotne pozyskano metodą badań ankietowych, wykorzystując technikę ankiety internetowej. Próba badawcza liczyła 442 przedsiębiorstwa zatrudniające ponad 50 pracowników, dobranych losowo spośród przedsiębiorstw prowadzących działalność na terenie Polski ${ }^{1}$. Wśród przebadanych przedsiębiorstw $37,1 \%$ prowadziło działalność wytwórczą, 36,9\% usługową oraz 26,0\% - handlową. Typowe badane przedsiębiorstwo dla każdego rodzaju działalności to przedsiębiorstwo, które: ocenia swój stopień przystosowania do współczesnej gospodarki rynkowej jako przeciętny na tle branży, obsługuje głównie przedsiębiorstwa, prowadzi działalność na rynku, na którym wymagania klientów zmieniają się istotnie, ale powoli, ocenia konkurencję na rynku jako silną, działa na rynku dojrzałym, należy na rynku do grupy czołowych firm o dominującym krajowym kapitale i nadzorze właścicielskim, ocenia swoją kondycję finansową jako korzystną, zatrudnia do stu pracowników. Typowe przedsiębiorstwo wytwórcze i handlowe prowadzi działalność na rynku krajowym, a przedsiębiorstwo usługowe na rynku regionalnym. Typowe przedsiębiorstwo wytwórcze i handlowe prowadzi działalność na rynku, na którym wyróżnia się kilka grup klientów o specyficznych wymaganiach, a typowe przedsiębiorstwo usługowe prowadzi na rynku, na którym klienci wymagają indywidualnego podejścia.

\section{Znaczenie podstawowych źródeł informacji marketingowej}

Jak już wspomniano, źródła, z których przedsiębiorstwa pozyskują informacje marketingowe, a które były rozważane w badaniu, to własne: ewidencja, obserwacje i doświadczenia, badania marketingowe oraz wyspecjalizowane agencje badań rynku, źródła wtórne zewnętrzne (tabela 1).

${ }^{1}$ Szczegółowe założenia badawcze, sposób doboru próby badawczej oraz techniczną stronę przebiegu badania przedstawiono w: [Kapera, Kuziak i Niestrój 2014, s. 21-28]. 
Tabela 1. Częstotliwość wyboru znaczenia różnych źródeł informacji marketingowych w przekroju prowadzonej działalności (w \%)

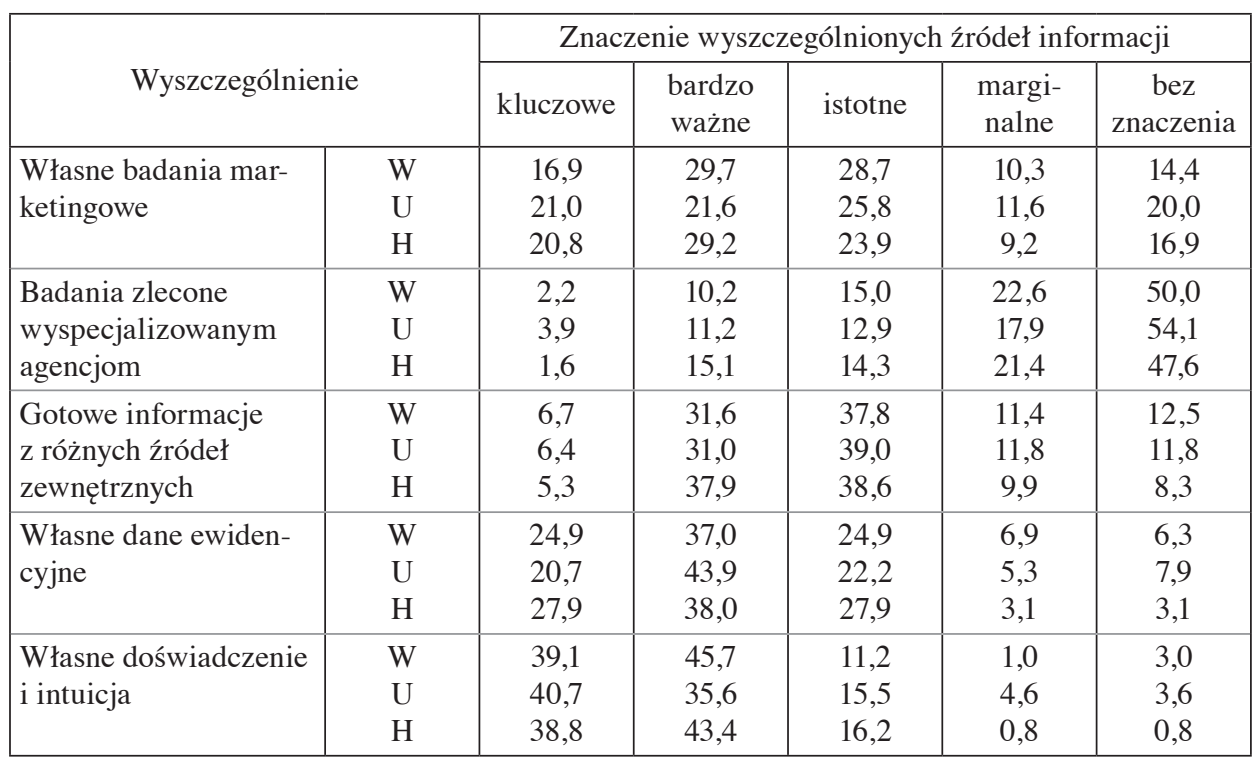

Objaśnienie: W - przedsiębiorstwa prowadzące działalność wytwórczą, U - przedsiębiorstwa prowadzące działalność usługową, $\mathrm{H}$ - przedsiębiorstwa prowadzące działalność handlową.

Źródło: opracowanie własne.

Analizując dane zamieszczone w tabeli 1, między innymi można dostrzec, że znaczenie poszczególnych źródeł informacji jest zróżnicowane, ale w taki sam sposób dla przedsiębiorstw prowadzących różnego rodzaju działalność. Własne doświadczenie i intuicja jako źródło informacji są zdecydowanie najczęściej wykorzystywane. W zależności od rodzaju działalności od $76 \%$ do prawie $85 \%$ przedsiębiorstw wskazywane jest to źródło ${ }^{2}$ jako kluczowe (około $40 \%$ przedsiębiorstw) i bardzo ważne. Jest to źródło marginalne i bez znaczenia dla co dwunastego przedsiębiorstwa usługowego, co dwudziestego piątego przedsiębiorstwa wytwórczego i dla co sześćdziesiątego drugiego przedsiębiorstwa handlowego. Ogólnie nie ma wielu różnic wskazań znaczenia tego źródła w przekroju cech przedsiębiorstw i cech obsługiwanych przez nie rynków.

Wskazania znaczenia tego źródła przez przedsiębiorstwa wytwórcze różnicują: konkurencyjna struktura rynku oraz kategoria nabywców finalnych. Przedsiębiorstwa prowadzące działalność na rynku rozproszonym częściej oceniają rozważane

2 Jako kluczowe badani wskazywali to źródło informacji marketingowej, które jest najczęściej wykorzystywane, a jako bardzo ważne, źródło wykorzystywane w drugiej, ewentualnie trzeciej kolejności co do częstotliwości wykorzystywania. 
źródło jako kluczowe (o 6 p.p.) $)^{3}$ i częściej jako kluczowe (o 13 p.p.) przedsiębiorstwa obsługujące głównie jednostki budżetowe. Żadne przedsiębiorstwo obsługujące głównie klientów indywidualnych nie ocenia tego źródła jako bez znaczenia i marginalnego. Wskazania znaczenia tego źródła przez przedsiębiorstwa usługowe różnicuje tylko intensywność konkurencji na rynku. Przedsiębiorstwa prowadzące działalność na rynku o słabej konkurencji rzadziej oceniają rozważane źródło jako kluczowe (o 25 p.p.), a częściej (o 18 p.p.) jako bez znaczenia. Przedsiębiorstwa prowadzące działalność na rynku o umiarkowanej konkurencji częściej oceniają rozważane źródło jako kluczowe (o 11 p.p.). Wskazania znaczenia tego źródła przez przedsiębiorstwa handlowe różnicują: kondycja finansowa firmy oraz dominujący kapitał i nadzór założycielski. Przedsiębiorstwa o dominującym kapitale i nadzorze zagranicznym oraz mieszanym rzadziej oceniają rozważane źródło jako kluczowe (odpowiednio o 19 p.p. i 14 p.p.). Jednocześnie żadne z tych przedsiębiorstw nie ocenia rozważanego źródła jako marginalnego i bez znaczenia. Przedsiębiorstwa o kapitale i nadzorze właścicielskim krajowym częściej (o 7 p.p.) oceniają to źródło jako kluczowe.

Także własna ewidencja jako źródło informacji marketingowej ma duże znaczenie, generalnie podobne dla przedsiębiorstw realizujących różny rodzaj działalności. Jako kluczowe i bardzo ważne ocenia to źródło od około $62 \%$ do $66 \%$ przedsiębiorstw (jako kluczowe średnio co czwarte przedsiębiorstwo wytwórcze i co piąte przedsiębiorstwo usługowe). Generalnie nie ma także wielu różnic wskazań znaczenia tego źródła w przekroju cech przedsiębiorstw i cech obsługiwanych przez nie rynków. Wskazania znaczenia tego źródła przez przedsiębiorstwa wytwórcze różnicuje tylko dynamika rynku. Przedsiębiorstwa działające na rynku szybko rozwijającym się częściej oceniają to źródło jako kluczowe (o 5 p.p.). Przedsiębiorstwa działające na rynku o tendencji schyłkowej rzadziej oceniają to źródło jako kluczowe (o 15 p.p.), a częściej jako marginalne (o 21 p.p.) i bez znaczenia (o 12 p.p.). Wskazania znaczenia tego źródła przez przedsiębiorstwa usługowe różnicują: dynamika rynku i stopień zróżnicowania potrzeb klientów. Przedsiębiorstwa działające na rynku szybko rozwijającym się rzadziej (o 6 p.p.) oceniają to źródło jako kluczowe, a także rzadziej (o 4 p.p.) jako kluczowe przedsiębiorstwa działające na rynku, na którym można wskazać kilka grup klientów o specyficznych wymaganiach. Wskazania znaczenia tego źródła przez przed-

${ }^{3}$ Dane liczbowe w punktach procentowych (p.p.) informują o odchyleniu pomiędzy procentem wskazań rodzaju znaczenia poszczególnych źródeł informacji przez przedsiębiorstwa o danej cesze względnie cesze obsługiwanego rynku a procentem wskazań rodzaju znaczenia poszczególnych źródeł informacji dla łącznie wszystkich przedsiębiorstw danego rodzaju działalności. Dalej wskazano tylko te odchylenia, które są najważniejsze i najciekawsze. Uwzględniono tylko te związki pomiędzy źródłami informacji a tymi cechami przedsiębiorstw i rynków, które okazały się statystycznie istotne. 
siębiorstwa handlowe różnicują także dynamika rynku i stopień zróżnicowania potrzeb klientów. Przedsiębiorstwa działające na rynku o tendencji schyłkowej częściej (o 6 p.p.) oceniają to źródło jako kluczowe. Przedsiębiorstwa obsługujące klientów wymagających indywidualnego podejścia częściej oceniają to źródło jako kluczowe (o 13 p.p.), a rzadziej (o 9 p.p.) - przedsiębiorstwa działające na rynku, gdzie wyróżnia się kilka grup klientów o specyficznych wymaganiach.

Własne badania marketingowe jako źródło informacji są rzadziej wykorzystywane, chociaż z podobną częstotliwością przez przedsiębiorstwa realizujące różny rodzaj działalności. Za kluczowe i bardzo ważne uznaje to źródło od ponad $42 \%$ do 50\% przedsiębiorstw (za kluczowe średnio co piąte przedsiębiorstwo usługowe i handlowe oraz co szóste przedsiębiorstwo wytwórcze). Jest to źródło bez znaczenia dla co siódmego przedsiębiorstwa wytwórczego, co piątego przedsiębiorstwa usługowego i co szóstego przedsiębiorstwa handlowego. Generalnie różnice wskazań znaczenia tego źródła w przekroju cech przedsiębiorstw i cech obsługiwanych przez nich rynków są niewielkie. Wskazania znaczenia tego źródła przez przedsiębiorstwa wytwórcze różnicują:

- odmienne potrzeby klientów. Przedsiębiorstwa prowadzące działalność na rynku, na którym brak większego zróżnicowania potrzeb klientów rzadziej (o 5 p.p.), uznają to źródło za kluczowe, a częściej (o 13 p.p.) - za bez znaczenia. Przedsiębiorstwa działające na rynku, na którym klienci wymagają indywidualnego podejścia, częściej uznają to źródło za kluczowe (o 5 p.p.);

- zmienność rynku. Przedsiębiorstwa działające na rynku, na którym wymagania klientów zmieniają się szybko, częściej oceniają to źródło jako kluczowe (o 10 p.p.) i rzadziej oceniają je jako bez znaczenia (o 6 p.p.). Częściej jako bez znaczenia (o 20 p.p.) oceniają to źródło przedsiębiorstwa działające na rynku, na którym zmiany wymagań klientów są mało istotne lub żadne i rzadziej jako kluczowe (o 8 p.p.). Przedsiębiorstwa działające na rynku, na którym zmiany wymagań klientów są istotne, ale powolne, rzadziej uznają to źródło za kluczowe (o 20 p.p.).

Wskazania znaczenia tego źródła przez przedsiębiorstwa usługowe różnicują:

- zmienność rynku. Przedsiębiorstwa prowadzące działalność na rynku, na którym wymagania klientów zmieniają się szybko, częściej oceniają to źródło jako kluczowe (o 6 p.p.) i rzadziej jako bez znaczenia (o 6 p.p.), natomiast przedsiębiorstwa prowadzące działalność na rynku, na którym zmiany potrzeb są mało istotne lub żadne, rzadziej oceniają to źródło jako kluczowe (o 7 p.p.) i częściej jako bez znaczenia (o 19 p.p.);

- intensywność konkurencji. Przedsiębiorstwa prowadzące działalność na rynku o umiarkowanej konkurencji częściej uznają to źródło za kluczowe (o 7 p.p.). Przedsiębiorstwa prowadzące działalność na rynku o słabej konkurencji rzadziej uznają to źródło za kluczowe (o 7 p.p.) i częściej za bez znaczenia (26 p.p.); 
- zasięg działania. Przedsiębiorstwa prowadzące działalność ma rynku regionalnym rzadziej oceniają to źródło jako kluczowe (o 10 p.p.) i częściej jako bez znaczenia (o 11 p.p.). Przedsiębiorstwa prowadzące działalność na rynku lokalnym rzadziej oceniają to źródło jako kluczowe (o 7 p.p.), ale także rzadziej jako bez znaczenia (o 7 p.p.);

- stopień zróżnicowania potrzeb klientów. Przedsiębiorstwa prowadzące działalność na rynku, na którym brak większego zróżnicowania potrzeb klientów, rzadziej oceniają to źródło jako kluczowe (o 3 p.p.), a częściej jako bez znaczenia (o 14 p.p.). Przedsiębiorstwa prowadzące działalność na rynku wymagającym indywidulanego podejścia do klienta częściej wskazują to źródło jako kluczowe (o 3 p.p.) i rzadziej jako bez znaczenia (o 7 p.p.).

Wskazania znaczenia tego źródła przez przedsiębiorstwa handlowe różnicują:

- zmienność rynku. Przedsiębiorstwa prowadzące działalność na rynku szybko rozwijającym się częściej uznają to źródło za kluczowe (o 5 p.p.) i rzadziej za bez znaczenia (o 4 p.p.);

- stopień zróżnicowania potrzeb klientów. Przedsiębiorstwa prowadzące działalność na rynku, na którym wymagania klientów zmieniają się szybko, częściej oceniają to źródło jako kluczowe (o 10 p.p.) i rzadziej jako bez znaczenia (8 p.p.). Przedsiębiorstwa prowadzące działalność na rynku o zmianach mało istotnych lub żadnych rzadziej oceniają to źródło jako kluczowe (o 11 p.p.), a częściej jako bez znaczenia (o 29 p.p.). Przedsiębiorstwa prowadzące działalność na rynku, na którym braknie większego zróżnicowania potrzeb klientów, rzadziej oceniają to źródło jako kluczowe (o 8 p.p.), a częściej jako bez znaczenia (o 16 p.p.). Przedsiębiorstwa prowadzące działalność na rynku wymagającym indywidualnego podejścia do klienta częściej oceniają to źródło jako kluczowe (o 11 p.p.) i rzadziej jako bez znaczenia (o 6 p.p.);

- stopień dostosowania firmy do współczesnej gospodarki rynkowej. Przedsiębiorstwa oceniające stopień przystosowania swojej firmy do współczesnej gospodarki rynkowej jako wyższy od przeciętnego w branży częściej uznają to źródło za kluczowe (o 5 p.p.), a rzadziej za bez znaczenia (o 8 p.p.).

Gotowe informacje marketingowe pochodzące $\mathrm{z}$ różnych źródeł zewnętrznych są zdecydowanie rzadziej wykorzystywane, chociaż z podobną częstotliwością przez przedsiębiorstwa o różnych rodzajach działalności. Za bardzo ważne uważa to źródło od ponad $38 \%$ do ponad $43 \%$ przedsiębiorstw (za kluczowe uważa średnio co piętnaste przedsiębiorstwo wytwórcze i usługowe oraz co dziewiętnaste przedsiębiorstwo handlowe). To źródło jest bez znaczenia dla co ósmego przedsiębiorstwa wytwórczego, co piątego przedsiębiorstwa wytwórczego i usługowego i co dwunastego przedsiębiorstwa handlowego. Generalnie różnice wskazań znaczenia tego źródła w przekroju cech przedsiębiorstw i cech obsługiwanych przez nich rynków są niewielkie. Wskazania znaczenia tego źródła przez przedsię- 
biorstwa wytwórcze różnicuje tylko kondycja finansowa firmy. Przedsiębiorstwa oceniające swoją kondycję finansową jako bardzo korzystną częściej oceniają to źródło jako kluczowe (o 20 p.p.), ale też częściej jako bez znaczenia (o 3 p.p.). Żadne przedsiębiorstwo oceniające swoją kondycję finansową jako trudną nie ocenia tego źródła jako kluczowe, a rzadziej jako bez znaczenia (o 6 p.p.).

Wskazania znaczenia tego źródła przez przedsiębiorstwa usługowe różnicuje:

- zmienność rynku. Przedsiębiorstwa prowadzące działalność na rynku, na którym zmiany wymagań klientów są mało istotne lub żadne, częściej oceniają to źródło jako kluczowe (o 5 p.p.), ale także częściej jako bez znaczenia (o 14 p.p.). Przedsiębiorstwa prowadzące działalność na rynku, na którym wymagania klientów zmieniają się szybko, rzadziej oceniają je jako kluczowe (o 4 p.p).

- stopień zróżnicowania potrzeb klientów. Przedsiębiorstwa prowadzące działalność na rynku, na którym brakuje większego zróżnicowania potrzeb klientów, częściej oceniają to źródło jako bez znaczenia (o 16 p.p.), a prowadzące działalność na rynku, na którym można wyróżnić kilka grup klientów o specyficznych wymaganiach rzadziej oceniają je jako bez znaczenia (o 8 p.p.).

- kondycja finansowa firmy. Przedsiębiorstwa będące w dobrej kondycji finansowej częściej oceniają to źródło jako kluczowe (o 4 p.p.), a rzadziej jako bez znaczenia (o 5 p.p.). Żadne z przedsiębiorstw będących w trudnej sytuacji finansowej nie ocenia go jako kluczowe, a częściej ocenia je jako bez znaczenia (o 8 p.p.).

Wskazania znaczenia tego źródła przez przedsiębiorstwa handlowe różnicuje tylko kondycja finansowa firmy. Przedsiębiorstwa oceniające swoją kondycję finansową jako bardzo korzystną częściej uznają to źródło za kluczowe (o 3 p.p.). Przedsiębiorstwa oceniające swoją kondycję finansową jako przeciętną częściej uznają to źródło za bez znaczenia (o 7 p.p.). Przedsiębiorstwa znajdujące się w trudnej kondycji finansowej rzadziej oceniają to źródło jako kluczowe (o 14 p.p.) i częściej jako bez znaczenia (o 12 p.p.).

Znikome znaczenie uznane za źródła informacji mają badania zlecane wyspecjalizowanym agencjom. Wszystkie typy przedsiębiorstw wskazują na znaczenie tego źródła z podobną częstotliwością. Za kluczowe i bardzo ważne uznaje to źródło od ponad $12 \%$ do prawie 17\% przedsiębiorstw (za kluczowe średnio co czterdzieste piąte przedsiębiorstwo wytwórcze, co dwudzieste szóste przedsiębiorstwo usługowe oraz co sześćdziesiąte trzecie przedsiębiorstwo handlowe). Jest to źródło bez znaczenia dla połowy przedsiębiorstw wytwórczych, ponad połowy przedsiębiorstw usługowych i prawie połowy przedsiębiorstw handlowych. Generalnie różnice wskazań znaczenia tego źródła w przekroju cech przedsiębiorstw i cech obsługiwanych przez nich rynków są znaczne. Wskazania znaczenia tego źródła przez przedsiębiorstwa wytwórcze różnicuje aż sześć cech: kategoria nabywców finalnych, stopień zróżnicowania potrzeb nabywców, intensywność 
konkurencji, konkurencyjna struktura rynku, kondycja finansowa firm oraz dominujący kapitał i nadzór właścicielski (tabela 2).

Tabela 2. Odchylenia wskazań znaczenia badań zlecanych wyspecjalizowanym agencjom jako źródła informacji (od wskazań łącznych) dla cech przedsiębiorstw wytwórczych i obsługiwanych przez nie rynków (w p.p.)

\begin{tabular}{|c|c|c|c|c|c|}
\hline \multirow[b]{2}{*}{ Wyszczególnienie } & \multicolumn{5}{|c|}{ Znaczenie źródeł informacji } \\
\hline & kluczowe & $\begin{array}{l}\text { bardzo } \\
\text { ważne }\end{array}$ & istotne & $\begin{array}{l}\text { margi- } \\
\text { nalne }\end{array}$ & $\begin{array}{c}\text { bez } \\
\text { znaczenia }\end{array}$ \\
\hline $\begin{array}{l}\text { Nabywcy finalni } \\
\text { - głównie konsumenci indywidualni } \\
\text { - głównie przedsiębiorstwa } \\
\text { - głównie jednostki budżetowe }\end{array}$ & $\begin{array}{c}+5 \\
-2 \\
0\end{array}$ & $\begin{array}{c}+10 \\
-2 \\
0\end{array}$ & $\begin{array}{c}-5 \\
- \\
+10\end{array}$ & $\begin{array}{l}-2 \\
- \\
+27\end{array}$ & $\begin{array}{c}-7 \\
+4 \\
-25\end{array}$ \\
\hline $\begin{array}{l}\text { Stopień zróżnicowania potrzeb } \\
\text { klientów } \\
\text { - brak większego zróżnicowania } \\
\text { - kilka grup klientów o specyficz- } \\
\text { nych potrzebach } \\
\text { - klienci wymagający indywidual- } \\
\text { nego podejścia }\end{array}$ & $\begin{array}{l}0 \\
- \\
-\end{array}$ & $\begin{array}{l}-3 \\
+4 \\
-3\end{array}$ & $\begin{array}{l}-14 \\
+2 \\
+6\end{array}$ & $\begin{array}{l}- \\
+4 \\
-3\end{array}$ & $\begin{array}{c}+20 \\
+9 \\
-\end{array}$ \\
\hline $\begin{array}{l}\text { Konkurencyjna struktura rynku } \\
\text { - dominuje jedna firma } \\
\text { - liczy się kilka dużych firm } \\
\text { - rynek rozproszony }\end{array}$ & $\begin{array}{l}0 \\
- \\
-\end{array}$ & $\begin{array}{l}+4 \\
- \\
-\end{array}$ & $\begin{array}{c}- \\
+3 \\
-11\end{array}$ & $\begin{array}{c}+20 \\
- \\
-5\end{array}$ & $\begin{array}{l}-21 \\
-5 \\
+17\end{array}$ \\
\hline $\begin{array}{l}\text { Konkurencja } \\
\text { - silna } \\
\text { - umiarkowana } \\
\text { - słaba }\end{array}$ & $\begin{array}{l}- \\
0 \\
0\end{array}$ & $\begin{array}{c}- \\
-3 \\
0\end{array}$ & $\begin{array}{c}-3 \\
+5 \\
-\end{array}$ & $\begin{array}{l}+3 \\
-4 \\
+7\end{array}$ & $\begin{array}{c}-2 \\
+3 \\
+22\end{array}$ \\
\hline $\begin{array}{l}\text { Dominujący kapitał i nadzór właści- } \\
\text { cielski } \\
\text { - kapitał krajowy } \\
\text { - kapitał zagraniczny } \\
\text { - kapitał mieszany }\end{array}$ & $\begin{array}{c}- \\
0 \\
+6\end{array}$ & $\begin{array}{l}- \\
-3 \\
-3\end{array}$ & $\begin{array}{c}-5 \\
+23 \\
-\end{array}$ & $\begin{array}{l}- \\
- \\
-\end{array}$ & $\begin{array}{c}+4 \\
-20 \\
-4\end{array}$ \\
\hline $\begin{array}{l}\text { Kondycja finansowa firmy } \\
\text { - bardzo korzystna } \\
\text { - korzystna } \\
\text { - przeciętna } \\
\text { - trudna }\end{array}$ & $\begin{array}{c}+8 \\
- \\
0 \\
0\end{array}$ & $\begin{array}{c}+5 \\
+2 \\
-3 \\
0\end{array}$ & $\begin{array}{c}- \\
- \\
- \\
-4\end{array}$ & $\begin{array}{l}+4 \\
-3 \\
+3 \\
+7\end{array}$ & $\begin{array}{c}-18 \\
- \\
+5 \\
+9\end{array}$ \\
\hline
\end{tabular}

Objaśnienie: - brak istotnych odchyleń; 0 - brak wskazań.

Źródło: opracowanie własne.

Analizując dane zamieszczone w tabeli 2, warto zwrócić uwagę na następujące fakty. Przedsiębiorstwa obsługujące głównie konsumentów indywidualnych częściej zlecają badania wyspecjalizowanym agencjom ocenia jako kluczowe 
(o 5 p.p.), a rzadziej jako bez znaczenia (o 7 p.p.). Żadne przedsiębiorstwo obsługujące głównie jednostki budżetowe nie ocenia tego źródła jako kluczowe, a zdecydowanie rzadziej ocenia je jako bez znaczenia (o 25 p.p.). Żadne przedsiębiorstwo działające na rynku, na którym brak większego zróżnicowania potrzeb klientów, nie ocenia tego źródła jako kluczowe, a częściej jako bez znaczenia (o 20 p.p.). Żadne przedsiębiorstwo prowadzące działalność na rynku, na którym dominuje jedna firma, nie uważa tego źródła za kluczowe, a rzadziej jako bez znaczenia (o 21 p.p.). Przedsiębiorstwa prowadzące działalność na rynku rozproszonym częściej oceniają to źródło jako bez znaczenia (o 17 p.p.). Żadne przedsiębiorstwo oceniające konkurencję na rynku, na którym prowadzą działalność jako słabą i umiarkowaną, nie uważa tego źródła za kluczowe. Przedsiębiorstwa działające na rynku o słabej konkurencji częściej uważają to źródło za bez znaczenia (o 22 p.p.). Przedsiębiorstwa o dominującym zagranicznym kapitale i nadzorze właścicielskim rzadziej uznają to źródło za bez znaczenia (o 20 p.p.), a żadne przedsiębiorstwo nie uznaje tego źródła za kluczowe. Przedsiębiorstwa oceniające swoją kondycję finansową jako bardzo korzystną częściej uznają to źródło za kluczowe (o 8 p.p.), a rzadziej za bez znaczenia (o 18 p.p.). Żadne przedsiębiorstwo oceniające swoją kondycję finansową jako przeciętną i trudną nie uważa tego źródła za kluczowe. Wskazania znaczenia tego źródła przez przedsiębiorstwa usługowe różnicuje: stopień przystosowania firmy do współczesnej gospodarki rynkowej, kategoria obsługiwanych nabywców, dominujący kapitał i nadzór założycielski oraz zmienność rynku. Przedsiębiorstwa obsługujące głównie konsumentów indywidualnych częściej oceniają to źródło jako kluczowe (o 6 p.p.), ale także częściej jako bez znaczenia (o 3 p.p.). Żadne przedsiębiorstwo obsługujące głównie jednostki budżetowe nie ocenia tego źródła jako kluczowe, a częściej jako bez znaczenia (o 28 p.p.). Żadne przedsiębiorstwo prowadzące działalność na rynku, na którym zmiany wymagań klientów są mało istotne lub żadne, nie ocenia tego źródła jako kluczowe i wskazują częściej jako bez znaczenia (o 14 p.p.). Żadne z przedsiębiorstw oceniających stopień przystosowania do współczesnej gospodarki jako w pełni zadowalający, ale niedostateczny, nie ocenia tego źródła jako kluczowe. Przedsiębiorstwa oceniające swoje przystosowanie do gospodarki jako przeciętne i niedostateczne częściej oceniają to źródło jako bez znaczenia (odpowiednio o 11 p.p. i 12 p.p.). Przedsiębiorstwa w których dominuje zagraniczny kapitał i nadzór założycielski częściej uznają to źródło za kluczowe (o 7 p.p.) i rzadziej za bez znaczenia (o 20 p.p.). Wskazania znaczenia tego źródła przez przedsiębiorstwa handlowe różnicuje dominujący kapitał i nadzór założycielski oraz kondycja finansowa firmy. Żadne z przedsiębiorstw o dominującym zagranicznym i mieszanym kapitale i nadzorze założycielskim nie ocenia tego źródła jako kluczowe a rzadziej jako bez znaczenia (odpowiednio o 25 p.p. i 16 p.p.). Przedsiębiorstwa będące w bardzo korzystnej kondycji finansowej częściej oceniają to źródło jako kluczowe 
(o 14 p.p.), a rzadziej jako bez znaczenia (o 10 p.p.). Żadne z przedsiębiorstw będące w kondycji finansowej korzystnej, przeciętnej i trudnej nie oceniają tego źródła jako kluczowe. Przedsiębiorstwa o korzystnej kondycji finansowej częściej oceniają to źródło jako bez znaczenia (o 7 p.p.), a przedsiębiorstwa o trudnej kondycji finansowej częściej oceniają źródło jako bez znaczenia (o 36 p.p.).

Podsumowując, można sformułować kilka wniosków:

- ogólnie można stwierdzić, że wszystkie przedsiębiorstwa, jeśli chodzi o wybór poszczególnych źródeł informacji marketingowej, zachowują się racjonalnie, dostosowując swoje decyzje w tym zakresie do rozpoznanych warunków działania firmy, tj. stanu otoczenia oraz wartości posiadanych zasobów. Szczególnie potwierdzają tę tezę ujawnione wskazania zróżnicowań korzystania z poszczególnych źródeł informacji w przekroju charakterystyk firm i cech obsługiwanego przez nie rynku;

- dla przedsiębiorstw wszystkich rodzajów działalności ważność poszczególnych źródeł informacji jest taka sama. Dominuje własne doświadczenie i intuicja, a najmniejsze znaczenie mają badania zlecane wyspecjalizowanym agencjom. Zastanawia względnie niskie znaczenie dla wszystkich typów przedsiębiorstw gotowych informacji pochodzących z różnych źródeł zewnętrznych. Może to wynikać z braku świadomości istnienia takich informacji oraz z braku techniki poszukiwania takich źródeł;

- zróżnicowanie znaczenia wykorzystywania różnych źródeł informacji przez przedsiębiorstwa w przekroju rodzaju działalności jest niewielkie, chociaż można dostrzec pewne prawidłowości. Przedsiębiorstwa wytwórcze częściej wykorzystują (w stosunku do pozostałych przedsiębiorstw) gotowe informacje pochodzące z różnych źródeł zewnętrznych. Przedsiębiorstwa usługowe częściej wykorzystują własne badania marketingowe, częściej zlecają badania wyspecjalizowanym agencjom rynku i częściej korzystają z własnego doświadczenia i intuicji. Przedsiębiorstwa handlowe częściej wykorzystują własne dane ewidencyjne;

- wśród przedsiębiorstw wytwórczych różnicuje znaczenie poszczególnych źródeł informacji łącznie osiem cech przedsiębiorstw i rynków. Najsilniej zróżnicowane jest ocenianie znaczenia jako źródła informacji badań zlecanych wyspecjalizowanym agencjom (sześć cech przedsiębiorstw i rynków), najsłabiej zróżnicowane jest korzystanie z własnych danych ewidencyjnych i gotowych informacji pochodzących z różnych źródeł zewnętrznych. Jeśli chodzi o przedsiębiorstwa usługowe, znaczenie poszczególnych źródeł informacji różnicuje łącznie dziewięć cech przedsiębiorstw i rynków. Najbardziej zróżnicowane jest wykorzystanie własnych badań marketingowych (sześć cech przedsiębiorstw i rynków), najsłabiej własne dane ewidencyjne oraz własne doświadczenie i intuicja (po dwie cechy). Wśród przedsiębiorstw handlowych, najsilniej oceniane jest zróżnicowanie znaczenia jako źródła informacji własnych badań marketingowych (cztery cechy), 
najsłabiej zróżnicowane jest wykorzystywanie własnego doświadczenia oraz gotowych informacji pochodzących z różnych źródeł zewnętrznych (po jednej cesze);

- analizując łącznie wskazania wszystkich typów przedsiębiorstw znaczenia poszczególnych źródeł informacji, daje się zauważyć, że zróżnicowanie wskazań ważności poszczególnych źródeł wywołuje dziesięć różnych cech przedsiębiorstw i obsługiwanych przez przedsiębiorstwa rynków. Najbardziej różnicują znaczenie źródeł informacji odmienne potrzeby nabywców (siedem przypadków), zmienność rynku (pięć przypadków) i kondycja finansowa firmy (pięć przypadków). Najsłabiej różnicuje znaczenie poszczególnych źródeł informacji zasięg działania przedsiębiorstw (jeden przypadek) oraz ocena stopnia przystosowania firmy do współczesnej gospodarki rynkowej (dwa przypadki). Wśród przedsiębiorstw wytwórczych najczęściej zróżnicowanie wywołuje kategoria finalnego nabywcy (pięć przypadków). Wśród przedsiębiorstw usługowych najczęściej zróżnicowanie wynika z odmiennych potrzeb klientów (siedem przypadków) i zmienności rynku (pięć przypadków), najsłabiej wskazania różnicuje zasięg działania firmy (jeden przypadek).

\section{4. Źródła kluczowe i bardzo ważne}

Przedmiotem dalszej analizy będą tylko źródła informacji, które dla przedsiębiorstw mają kluczowe i bardzo ważne znaczenie (łącznie). Pozwoli to na ukazanie znaczenia (ranking) poszczególnych źródeł informacji w procesie zdobywania informacji marketingowej przez przedsiębiorstwa.

Analizując dane zamieszczone w tabeli 3 można między innymi dostrzec, że znaczenie poszczególnych źródeł informacji jest zróżnicowane, przy czym ogólnie tak samo dla przedsiębiorstw realizujących różny rodzaj działalności. Najczęściej przedsiębiorstwa oceniają wykorzystanie jako źródła informacji własne doświadczenie i intuicję (średnio co trzecie przedsiębiorstwo), przy czym nieco częściej przedsiębiorstwa wytwórcze. Drugim co do ważności źródłem informacji jest własna ewidencja (średnio dla co czwartego przedsiębiorstwa). To źródło nieznacznie częściej wykorzystują przedsiębiorstwa usługowe. Duże znaczenie własnej ewidencji jako źródła informacji marketingowej jest prawdopodobnie efektem dość istotnych modyfikacji systemu gromadzenia i przekształcania informacji, pozyskiwanych w różny sposób o zjawiskach i zdarzeń przebiegających wewnątrz przedsiębiorstwa, jak i w jego otoczeniu. Dzięki temu wzrosła sprawność systemu informacji wewnętrznej, dając możliwość wykorzystania posiadanych informacji w szerszym zakresie. Własne badania marketingowe jako źródło informacji marketingowej wykorzystuje średnio co piąte przedsiębiorstwo, przy czym częściej przedsiębiorstwa handlowe. Gotowe informacje pochodzące 
Tabela 3. Częstotliwość wskazań znaczenia kluczowego i bardzo ważnego poszczególnych źródeł informacji w przekroju rodzaju działalności (w \%)

\begin{tabular}{|l|c|c|c|}
\hline \multirow{2}{*}{ Wyszczególnienie } & \multicolumn{3}{c|}{ Rodzaj działalności } \\
\cline { 2 - 4 } & wytwórcza & usługowa & handlowa \\
\hline Własne badania marketingowe & 19,1 & 18,0 & 19,4 \\
\hline $\begin{array}{l}\text { Badania zlecone wyspecjalizowanym } \\
\text { agencjom }\end{array}$ & 5,1 & 6,4 & 6,4 \\
\hline $\begin{array}{l}\text { Gotowe informacje z różnych źródeł } \\
\text { zewnętrznych }\end{array}$ & 15,6 & 15,8 & 16,8 \\
\hline Własne dane ewidencyjne & 25,4 & 27,5 & 25,5 \\
\hline Własne doświadczenie i intuicja & 34,8 & 32,3 & 31,9 \\
\hline Ogółem & 100,0 & 100,0 & 100,0 \\
\hline
\end{tabular}

Źródło: opracowanie własne.

z różnych źródeł zewnętrznych są średnio wykorzystywane przez co szóste przedsiębiorstwo, przy czym częściej korzystają z tego źródła przedsiębiorstwa handlowe. Badania zlecane wyspecjalizowanym agencjom jako źródło informacji marketingowej są wykorzystywane z najmniejszą częstotliwością (średnio co szesnaste przedsiębiorstwo), przy czym najrzadziej przez przedsiębiorstwa wytwórcze (średnio co dziewiętnaste przedsiębiorstwo). Ranking częstotliwości wykorzystywania poszczególnych źródeł informacji dla przedsiębiorstw prowadzących różne rodzaje działalności jest identyczny, przy czym dystanse pomiędzy częstotliwościami są odmienne. Przykładowo własne dane ewidencyjne w stosunku do doświadczenia i intuicji są wykorzystywane rzadziej, ale przez przedsiębiorstwa wytwórcze o 9 p.p., przez przedsiębiorstwa usługowe o 5 p.p., a przez przedsiębiorstwa handlowe o 6 p.p. Także różnice pomiędzy częstotliwością wykorzystywania własnych badań marketingowych a częstotliwością wykorzystywania własnych danych ewidencyjnych w przekroju rodzaju działalności są odmienne. Przedsiębiorstwa wytwórcze i handlowe rzadziej wykorzystują własne badania marketingowe o ponad 6 p.p., a przedsiębiorstwa usługowe o prawie 10 p.p.

Źródła informacji marketingowej wykorzystywane w procesie gromadzenia informacji można grupować w różnych przekrojach. Standardowa klasyfikacja to podział na źródła pierwotne i źródła wtórne oraz na wewnętrzne i zewnętrzne. Poprzez nałożenie na siebie klasyfikacji na podstawie wymienionych kryteriów, można wyróżnić cztery podstawowe kategorie źródeł informacji, uporządkowane zgodnie z ich efektywnością wykorzystania, tj. źródła: wtórne wewnętrzne, wtórne zewnętrzne, pierwotne wewnętrzne, pierwotne zewnętrzne. 
W tabeli 4 zestawiono częstotliwości wykorzystywania poszczególnych kategorii źródeł w procesie pozyskiwania informacji marketingowych przez przedsiębiorstwa w przekroju rodzaju działalności.

Tabela 4. Znaczenie poszczególnych kategorii źródeł informacji w przekroju rodzaju działalności (w \%)

\begin{tabular}{|l|c|c|c|c|c|c|c|c|c|}
\hline \multirow{2}{*}{ Wyszczególnienie } & \multicolumn{3}{|c|}{ Źródła pierwotne } & \multicolumn{3}{c|}{ Źródła wtórne } & \multicolumn{3}{c|}{ Ogółem } \\
\cline { 2 - 10 } & $\mathrm{W}$ & $\mathrm{U}$ & $\mathrm{H}$ & $\mathrm{W}$ & $\mathrm{U}$ & $\mathrm{H}$ & $\mathrm{W}$ & $\mathrm{U}$ & $\mathrm{H}$ \\
\hline Źródła zewnętrzne & 5,1 & 6,4 & 6,4 & 15,6 & 15,8 & 16,8 & 20,7 & 22,2 & 23,2 \\
\hline Źródła wewnętrzne & 19,1 & 18,0 & 19,4 & 60,2 & 59,8 & 57,4 & 79,3 & 77,8 & 76,8 \\
\hline Ogółem & 24,2 & 24,4 & 25,8 & 75,8 & 75,6 & 74,2 & 100,0 & 100,0 & 100,0 \\
\hline
\end{tabular}

Objaśnienie: $\mathrm{W}$ - przedsiębiorstwa wytwórcze, $\mathrm{U}$ - przedsiębiorstwa usługowe, $\mathrm{H}$ - przedsiębiorstwa handlowe.

Źródło: obliczenia własne.

Analizując dane zamieszczone w tabeli 4 można między innymi stwierdzić, że ogólnie dla wszystkich przedsiębiorstw znaczenie źródeł pierwotnych jest małe. Z tych źródeł korzysta średnio co czwarte przedsiębiorstwo, przy czym częściej przedsiębiorstwa handlowe. Także małe jest znaczenie źródeł zewnętrznych. $Z$ tych źródeł korzysta średnio co piąte przedsiębiorstwo, przy czym rzadziej przedsiębiorstwa wytwórcze. Zwraca uwagę racjonalność zachowań przedsiębiorstw. Zdecydowanie przeważają najtańsze źródła informacji, czyli wtórne wewnętrzne (ponad 60\% wskazań wśród przedsiębiorstw wytwórczych i ponad 57\% wśród przedsiębiorstw handlowych), a najrzadziej są wykorzystywane źródła pierwotne zewnętrzne (średnio co dwudzieste przedsiębiorstwo wytwórcze i co szesnaste przedsiębiorstwo usługowe i handlowe). Ze źródeł pierwotnych wewnętrznych i źródeł wtórnych zewnętrznych przedsiębiorstwa w zasadzie korzystają z podobną częstotliwością, chociaż obserwuje się pewne różnice w przekroju rodzajów działalności. Częściej źródła pierwotne wewnętrzne (w stosunku do źródeł wtórnych zewnętrznych) wykorzystują przedsiębiorstwa wytwórcze (o prawie 4 p.p.) i przedsiębiorstwa usługowe (o ponad 2 p.p.), a rzadziej przedsiębiorstwa handlowe (o prawie 3 p.p.). Może to także wynikać z faktu, że w Polsce infrastruktura informacyjna rynku (źródła wtórne zewnętrzne) w dalszym ciągu jest słabo rozwinięta, a także jakość informacji pochodzących ze źródeł zewnętrznych nie jest wysoka. Skłania to przedsiębiorstwa do uruchamiania własnych procedur pozyskiwania informacji. Ta dominacja źródeł wtórnych wewnętrznych nad źródłami zewnętrznymi może wynikać także z traktowania przez przedsiębiorstwa problemów marketingowych jako problemów operacyjnych. 


\section{Zakończenie}

Zróżnicowanie znaczenia poszczególnych źródeł informacji marketingowej dla przedsiębiorstw wszystkich rodzajów działalności ogólnie jest niewielkie. Dominuje własne doświadczenie i intuicja a najmniejsze znaczenie mają badania zlecane wyspecjalizowanym agencjom. Zróżnicowanie znaczenia wykorzystywania poszczególnych źródeł informacji przez przedsiębiorstwa w przekroju rodzaju działalności jest niewielkie, a mianowicie:

- przedsiębiorstwa wytwórcze częściej wykorzystują gotowe informacje pochodzące z różnych źródeł zewnętrznych,

- przedsiębiorstwa usługowe częściej wykorzystują własne badania marketingowe, częściej zlecają badania wyspecjalizowanym agencjom rynku i częściej korzystają z własnego doświadczenia i intuicji,

- przedsiębiorstwa handlowe częściej wykorzystują własne dane ewidencyjne.

Zastanawia względnie niskie znaczenie dla przedsiębiorstw wszystkich rodzajów działalności gotowych informacji pochodzących z różnych źródeł zewnętrznych. Może to być spowodowane wieloma czynnikami, np.: brakiem świadomości istnienia takich źródeł, brakiem techniki poszukiwania takich źródeł, świadomością, że jakość informacji pochodzących ze źródeł zewnętrznych nie jest wysoka, traktowania przez przedsiębiorstwa problemów marketingowych jako problemów operacyjnych, a także dlatego że w Polsce infrastruktura informacyjna rynku (źródła wtórne zewnętrzne) jeszcze ciągle jest słabo rozwinięta.

Wśród przedsiębiorstw wytwórczych znaczenie poszczególnych źródeł informacji różnicuje łącznie osiem cech przedsiębiorstw i rynków. Najbardziej zróżnicowane jest znaczenie jako źródło informacji badań zlecanych wyspecjalizowanym agencjom. Wśród przedsiębiorstw usługowych znaczenie poszczególnych źródeł informacji różnicuje łącznie dziewięć cech przedsiębiorstw i rynków. Najbardziej zróżnicowane jest wykorzystanie własnych badań marketingowych. Wśród przedsiębiorstw handlowych, najsilniej oceniane jest zróżnicowanie znaczenia jako źródła informacji własnych badań marketingowych (cztery cechy przedsiębiorstw i rynków).

Pogłębione poszukiwanie innych czynników różnicujących znaczenie poszczególnych źródeł informacji marketingowej wśród przedsiębiorstw, ze szczególnym uwzględnieniem rodzaju prowadzonej działalności, to kierunek dalszych prac nad podjętym $w$ artykule problemem.

\section{Literatura}

Dietl J. [1998], Orientacja marketingowa polskich przedsiębiorstw, „Master of Business Administration", nr 2. 
Fonfara K. [2001], Rynkowa orientacja polskich przedsiębiorstw, „Marketing i Rynek”, nr 12.

Kaczmarczyk S. [2002], Badania marketingowe. Metody i techniki, PWE, Warszawa.

Kapera K., Kuziak M., Niestrój R. [2014], Założenia, przebieg badań i ocena zebranego materiału [w:] Marketing polskich przedsiębiorstw w 25-leciu gospodarki rynkowej, red. R. Niestrój, Fundacja Uniwersytetu Ekonomicznego w Krakowie, Kraków.

Kędzior Z. [1997], Orientacja marketingowa w przedsiębiorstwach (próba identyfikacji), „Marketing i Rynek”, nr 7.

Kowal W. [2012], Rozwój koncepcji zarzadzania marketingowego w świetle wyników badań polskich przedsiębiorstw, „Handel Wewnętrzny”, t. 9-10, nr 1.

Mazuerk-Łopacińska K. [2002], Zachowania nabywców jako podstawa strategii marketingowej, Wydawnictwo Akademii Ekonomicznej we Wrocławiu, Wrocław.

Pilarski R., Rawski M. [1999], Informacje marketingowe w procesie podejmowania decyzji rynkowych [w:] Kierunki rozwoju zarzadzania marketingowego w Polsce, red. J. Altkorn, Akademia Ekonomiczna w Krakowie, Wydział Zarządzania, Kraków.

Rawski M. [2012], Informacyjne podstawy decyzji marketingowych [w:] Podstawy marketingu, red. A. Czubała, PWE, Warszawa.

Sojkin B. [2009], Informacyjne podstawy decyzji marketingowych, PWE, Warszawa.

Szostek D. [2012], Stan i rozwój marketingu w przedsiębiorstwach funkcjonujacych na terenie polski, ,Marketing i Rynek”, nr 1.

Wilmańska-Sosnowska S. [1998], Funkcja marketingowa w przedsiębiorstwach handlowych w świetle badań [w:] Marketing 2001, red. T. Rydel, Uniwersytet Gdański, Sopot.

\section{The Diversification of Sources of Marketing Information by Business Activity Type - Research Results}

(Abstract)

The aim of the publication is to show the importance of different sources of marketing information in companies conducting different types business (manufacturing, services, trade) on the Polish market. The theses are formulated based on the results of research conducted by the Marketing Department of the Cracow University of Economics in 2013. The subject of the research was: "The scope and conditions of marketing used by companies in Poland". For all the companies researched, the validity of the various sources of information is the same. The companies' own experience and intuition prevail as the most important sources of information while the least important was research commissioned to specialised agencies. For the companies across all activity types, the importance of the various sources of information is the same. Manufacturing companies often use ready-made information from various external sources. Service companies prefer to use their own marketing research, market research outsourced to specialised agencies, and they also often use their own experience and intuition. Trading companies often use their own data.

Keywords: marketing, marketing information, marketing information sources, primary sources of information, secondary sources of information, internal sources of information, external sources of information. 